\title{
原著論文
}

\section{上下顎レシン床総義歯粘膜面部の重合に伴う 経日的形態変化について}

\author{
高橋裕
Three Dimensional Changes of the Denture Base of the Complete Denture following Polymerization

\author{
Yutaka Takahashi
}

\begin{abstract}
The objective of this study was to clarify some of the dimensional change patterns of the denture base of the complete denture following polymerization. Dimensional changes of three polymerization method types were compared. The complete dentures were measured by using the three dimensional measurement system.
\end{abstract}

The results obtained were summarized as follows.

1. Dimensional changes from the original model immediately after polymerization of complete upper and lower dentures were recorded and all three polymerization methods produced shrinkage on all three axes toward the center. Heat-cured resin samples and microwave-cured resin samples showed the same shrinkage with pour-type resin samples only showing $1 / 2$ that amount.

2. The gradual dimensional changes occuring after polymerization up until 4 weeks were also recorded. The heat-cured resin samples showed no additional changes but remained in its shrunken state. The pour-type resin samples began to enlarge until almost all of them reached the original model size within 4 weeks. The microwave-cured resin samples began to enlarge but only slightly and then soon stopped changing.

3. All polymerization method types showed more dimensional change in the lower plate than in the upper plate.

Key words : three dimensional change, complete denture, denture base, three dimensional measurement system

\section{I. 緒言}

義歯床用材料は, 1930 年代にポリメタクリル酸メチル

福岡歯科大学歯科補緅学第一蓝座 (主任 : 羽生哲也教授)

The 1 st Department of Prosthodontics, Fukuoka Dental College (Chief : Prof. Tetsuya Habu)

平成元年 8 月 10 日受付
(PMMA) が開発され，その後 Sweeny が粉液重合法を 考案したことによって, 1940 年代には，ゴム床からレジ ン床に変わっていった. レジン床義歯は, 開発されてす でに半世紀を経た今日でも，重合方法などに検討を加え られつつ臨床に広く使用されている.

レジン床義歯の重合方法は, 従来から主に加熱重合法 が用いられているが，その他に常温重合型レジンによる 流し込み法や，また最近では，マイクロ波重合法や可視 
光線重合法なども使用されはじめている.

総義歯の維持安定に関与寸る因子としては, (1) 義歯床 の大きさ, (2) 床縁形態, (3) 床縁封鎖性, (4) 床粘膜面部の 寸法再現性, (5) 咬合関係などが考えられるが, この中で 義歯床粘膜面部の寸法再現性は総義歯の維持に直接関連 の樑い因子のひとつにあげられる.

また義歯床にみられる変形には，印象採得時および模 型作製時におきる変形, 重合過程に生じる変形, そして 口腔内装着後に咀嚼などの外力でおきる変形等が考えら れ，この中で重合過程におこる変形の占める割合はかな り大きいといわれている.

総義歯粘膜面部の適合性については，すでに多くの研 究業績が報告されており, (1) 重合值後の総義歯と作業模 型との間にみられる間隙を測定したもの ${ }^{1 \sim 5)}$, (2) 総義歯 を原型や作業模型にもどしその間隙を測定したもの ${ }^{6,7)}$, (3) 総義歯の各測定点間の寸法変化や, 各測定点の浮き 上がりをみたもの ${ }^{8 \sim 11)}$, (4) コンパレーターなどを用いて 断面的な形態を測定したもの ${ }^{12 \sim 15)}$, (5) 総義歯の各測定点 の寸法変化と粘膜面からの浮き上がりを合成したもの ${ }^{16)}$, (6) 三次元座標測定機を用いて，各測定点間の寸法変 化や義歯床の粘膜面からの浮き上がりをみたもの などがある.これらの研究は，部分的な寸法変化や形態 変化をみたもので，義歯床粘膜面部の重合に伴う変形に ついての全容を把握したものとは考え難い.

そこで，上下顎レジン床総義苗粘膜面部の寸法再現性 を詳細に検討し，上下顎レジン床総義歯粘膜面全体につ いての形態的変化を三次元的にとらえ，原型との適合性 を比較検討する目的で，三次元座標測定機を用いて，義 歯床粘膜面部の重合に伴う寸法変化とその後引き続き起 こる経日的な寸法変化を, 重合方法の異なる 3 種の床用 レジンについて計測するとともに，この結果からこれら の義歯を口腔内に装着した状態を予測し，その適合性に ついて考察を行った.

\section{II. 実験材料および実験方法}

\section{1. 実験材料}

今回実験に用いた床用レジンは，下記に示す重合方法 の異なる 3 種とした.

1）加熱重合型レジンとして, Acron（而至社製, 以下 AC と略す) [Powder \#280921, Liquid \#120561]

2）流し込み型レジンとして, Pour Resin（松風社製, 以下 PR と略す) [Powder \#018720, Liquid \#128645]

3）マイクロ波重合型レジンとして, Acron MC（而
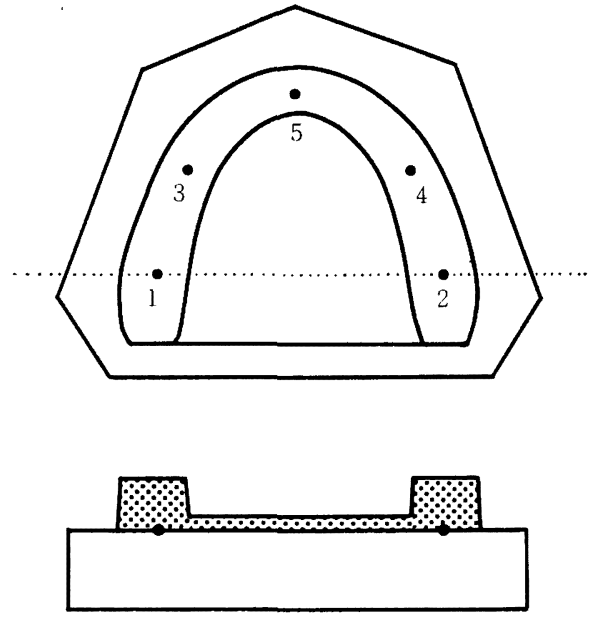

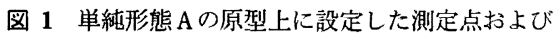
レジン床

至社製，以下MC と略す) [Powder \#121261, Liquid \#171261]

\section{2. 実験方法}

実験 I として, 上下頇レジン床総義歯の複雑な形態変 化をより詳細に検討するための前準備として，上下顎総 義歯を想定した単純形態レジン床について重合に伴う寸 法変化の計測を行い，つぎに，実験 II として上下䫑レジ ン床総義歯について重合直後から 4 週間後まで経日的な 寸法変化の計測を行った.

1）実験 I 。単純形態レジン床

上顎総義歯を想定した単純形態のレジン床を単純形態 A (図 1), 下顎総義歯を想定した単純形態レジン床を単 純形態 B (図 2) とした.

単純形態 $\mathrm{A}$ は, 上顎総義歯の口蓋部と顎堤部を平坦化 した咬合床を想定した形態で，単純形態 Bは，下䫑総義 歯の顎堤部を平坦化した咬合床を想定したもので，単純 形態Aから口蓋部を取り除いた形態とし，測定点は，左 右の大臼歯および犬歯の各相当部と正中部の合計 5 力所 に設定した.

実験は，まず図 $1 ， 2$ に示した形態にオリジナルレジ ン床を自作し，つぎに石育とシリコーンで採得したコア をガイドとして，測定点を設定した測定用副模型上に才 リジナルレジン床と同一の形態になるように蠟型の複製 を行った.つぎに $\mathrm{AC}$ と $\mathrm{MC}$ は, 而至社製埋没用石望 ADVASTONE で, PR は松風社製寒天印象材ポアーゲル を用いて埋没し，重合作製した。

重合条件は, $\mathrm{AC}$ は $70^{\circ} \mathrm{C}$ の温水中 90 分間, 沸騰水中 


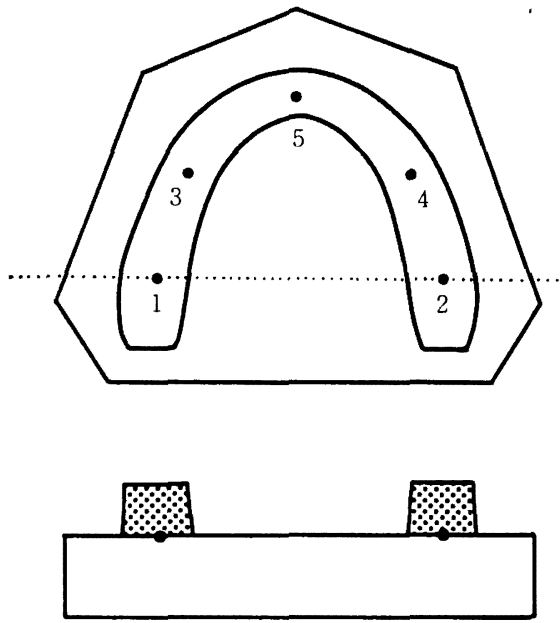

図 2 単純形態 B の原型上に設定した測定点および レジン床

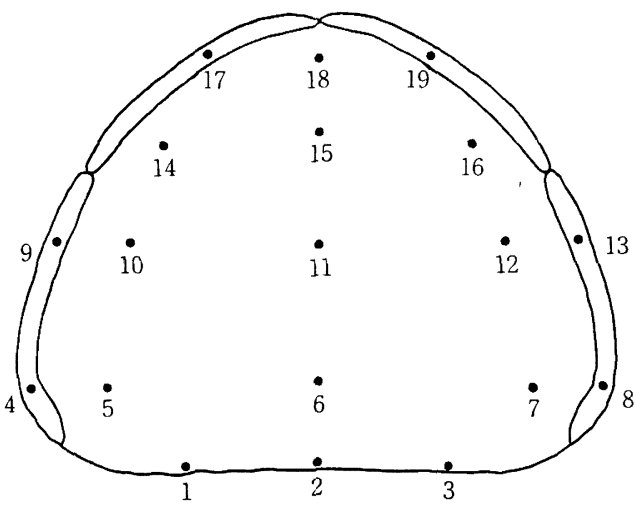

図 3 上領総義菌粘膜面部の測定点の位固

30 分間で重合し, 室温で放冷後に取り出しを行った. PR は $50^{\circ} \mathrm{C}$ 温水中 $4 \mathrm{~kg} / \mathrm{cm}^{2}$ 加圧下で 20 分間重合を行い, 30 分間室温で放冷後, 取り出しを行った. MC は, 出力 $500 \mathrm{~W}$ の電子レンジでマイクロ波を 3 分閒照射し, 30 分 間室温で放冷し，水中にて 30 分間冷却後に取り出しを 行った.

試料は各レジンの種類および各形態ごとに 5 林ずつ, 合計 30 床を作製した。 また測定期間中は，試料を $37^{\circ} \mathrm{C}$ 温水中に浸漬保存した.

2）実験 II．上下顎レジン床総義歯

原模型には上下無歯䪽エポキシレジン製模型（ニッシ ン社製 G 1-402)を用いた。

上顎の測定点は, 図 3 に示したように, 左右の第 2 大 臼歯，第 2 小臼歯，犬歯の各歯槽頂相当部および切歯乳 頭部, 口蓋正中部, 床後縁部之第 2 大臼歯, 第 2 小目蒾,

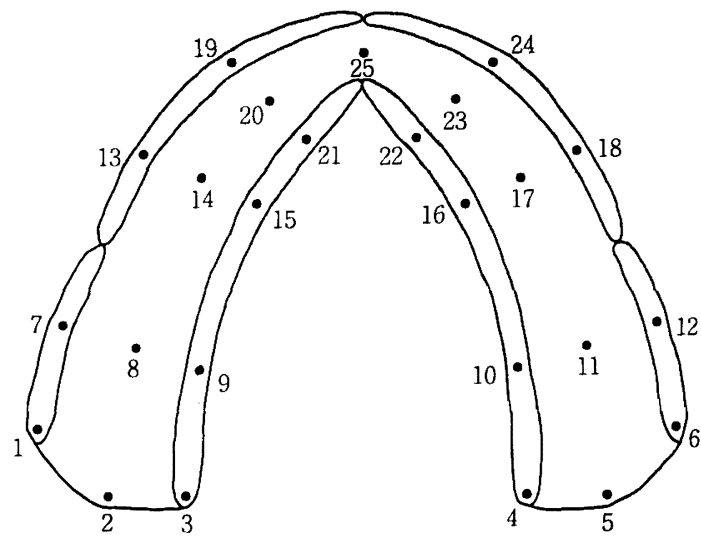

図 4 下矤総義歯粘膜面部の測定点の位置

前歯の各辺縁相当部の合計 19 力所に設定した.

下顎の測定点は，図 4 のように，第 2 大臼歯，第 2 小 臼歯，犬歯の各舌側および煩側辺縁と歯槽頂相当部そし て下顎正中歯槽頂部と白後隆起部の合計 25 力所に設 定 した.

オリジナル義歯は，本学総義歯模型実習に準じて作製 し，人工歯には松風社製 REAL CROWN T 4 および BIO-ACE RESIN TEETH M 30 を用いた. このオリジ ナル義歯をもとに，测定点を設定した測定用副模型上に 単純形態と同様の方法で蠟義歯を複製した。 また埋没, 重合操作および義歯の保存も，実験 I と同様の条件で行 った.

試料はレジンの種類ごとにそれぞれ 5 床ずつ上下頡合 わせて 30 床を作製した.

\section{3. 測定方法}

測定には，東京精密社製三次元デジタル座 標測 定 機 XYZAX-M 400 を用いた. 実験 I， IIを通じて，測定点 の形態は新たに開発した高橋ら ${ }^{21)}$ の方法を採用した。測 定点を設定した副模型を原型として，この位置を測定記 録し，その副模型上で作製したレジン床の粘膜面に転刻 された各測定点を, 重合直後から $6,12,24$ 時間後, 3,7 日後, 2,4 週閒後の 8 段階について経日的に測定を行っ た.

今回の実験では，原型から重合直後までの寸法変化を 重合変形, 重合直後から 4 週間後までの寸法変化を経日 的変形と規定した.

基準平面の設定方法は，上頢総義歯では，稲永ら ${ }^{17,18)}$, 羽生ら ${ }^{19)}$, 澤村ら ${ }^{20)}$ の方法に準じ, Point 5, 7, 18 の 3 点 を結んでできる平面を基準平面とし, Point 5,7 を結ん だ直線を X軸，このX軸に值交する直線を $\mathrm{Y}$ 軸，基準平 

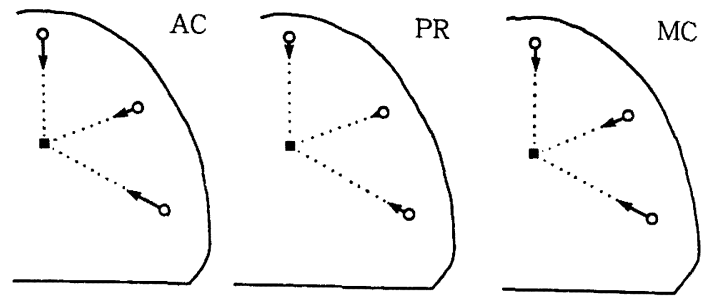

図 5 単純形態 $\mathrm{A}$ の重合変形

$\bigcirc:$ 原型の測定点の位圆, $\rightarrow$ : 重合変形の方向と変化量 $(\times 50), \square:$ 基準点
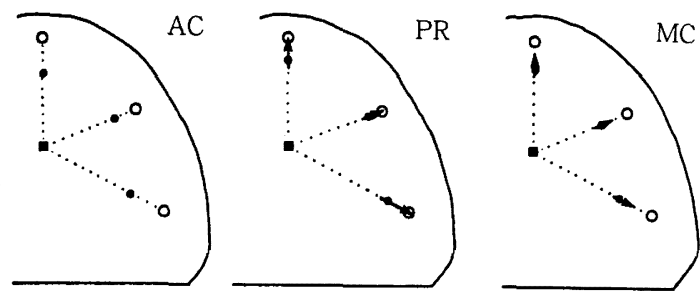

図 6 单純形態 $\mathrm{A} の$ 経日的変形

$\bigcirc:$ 原型の測定点の位置, ○:重合変形の位膡 $(\times 50), \rightarrow$ : 経日的変形の方向と変化䱿 $(\times 50)$, 口: 基淮点
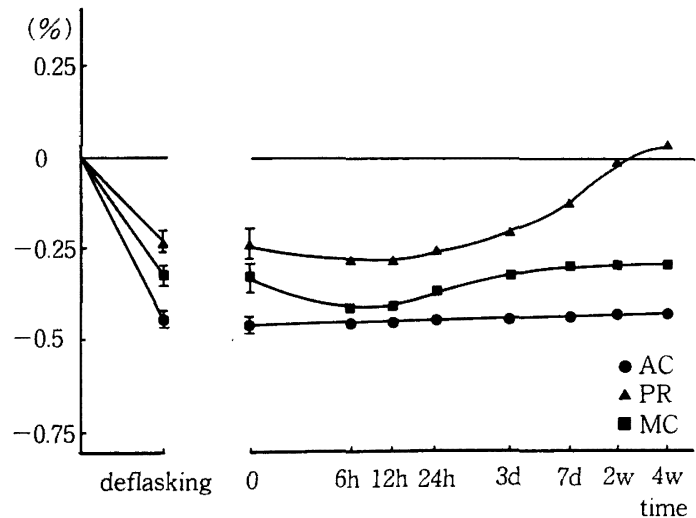

图 7 单純形態 A（Point 1) の重合直後の寸法変化とその 後の経日的寸法変化 ( $h:$ hour, d: day, w : week)

面に值交する值線を $Z$ 軸とした。 また Point $5,7,18$ の 3 点によってできる三角形の中点を基準点とした.

単純形態 $\mathrm{A} お$ よび単純形態 $\mathrm{B}$ の実験では, Point 1,2 , 5 によってできる平面を，下鿓総義歯では，Point 8, 11, 25 の 3 点を結んでできる平面を基準平面に設定し, 上䫟 総義歯と同様に基準点を定めた.

測定結果は，原型上の基準平面と各段階の義歯床粘膜 面上の基準平面を, 基準点を中心として重ね合わせ, 原 型に対する寸法変化として表した. さらに，各測定点の 测定結果を重合変形と経日的変形に分けて, 測定の段階
表 1 単純形態 A（Point 1) の分散分析表

\begin{tabular}{|c|c|c|c|c|c|c|}
\hline & & 装因 & SS & DF & V & $\mathrm{F}$ - 值 \\
\hline \multirow[t]{9}{*}{ 重合変形 } & \multirow[t]{3}{*}{$\mathrm{AC}$} & 級閒 & 1.536 & 1 & 1.536 & \multirow[t]{3}{*}{$1095.81 * *$} \\
\hline & & 鞉差 & 0.039 & 28 & 0.001 & \\
\hline & & 会計 & 1.575 & 29 & & \\
\hline & \multirow[t]{3}{*}{ PR } & 級間 & 0.395 & 1 & 0.395 & \multirow[t]{3}{*}{$182.52 * *$} \\
\hline & & 諒差 & 0.061 & 28 & 0.002 & \\
\hline & & 合計 & 0.456 & 29 & & \\
\hline & \multirow[t]{3}{*}{$\mathrm{MC}$} & 級閒 & 0.782 & 1 & 0.782 & \multirow[t]{3}{*}{$240.37 * *$} \\
\hline & & 誤差 & 0.091 & 28 & 0.003 & \\
\hline & & 台計 & 0.873 & 29 & & \\
\hline \multirow[t]{9}{*}{ 経日的变形 } & \multirow[t]{3}{*}{$\mathrm{AC}$} & 級間 & 0.022 & $\tau$ & 0.003 & \multirow[t]{3}{*}{$1.43-$} \\
\hline & & 証稁: & 0.248 & 112 & 0.002 & \\
\hline & & 台尌 & 0.270 & 119 & & \\
\hline & \multirow[t]{3}{*}{$\mathrm{PR}$} & 秋間 & 1.408 & 7 & 0.201 & \multirow[t]{3}{*}{$41.92 * *$} \\
\hline & & 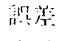 & 0.537 & 112 & 0.005 & \\
\hline & & 台計 & 1.945 & 119 & & \\
\hline & \multirow[t]{3}{*}{$M C$} & 新間 & 0.258 & 7 & 0.037 & \multirow[t]{3}{*}{$6.39 * *$} \\
\hline & & 器差 & 0.646 & 112 & 0.006 & \\
\hline & & 台計 & 0.904 & 119 & & \\
\hline
\end{tabular}

について一元配置の分散分析を行った.

\section{III. 実験結果}

\section{1. 実 験 I}

1）単純形態 A（上顎総義歯を想定した単純形態レジ ン床)

単純形態 $\mathrm{A}$ の重合変形を図 5 に, 経日的変形を図 6 に 示し, 図中の矢印は基準点を中心とした各測定点の寸法 変化の方向を, 矢印の長さは寸法変化量を 50 倍に拡 大 して示した.

重合変形は, $\mathrm{AC}, \mathrm{PR}, \mathrm{MC}$ の 3 種とも, 床全体がほぼ 均等に基準点方向へ収縮した。経日的変形は, ACには ほとんど寸法変化がみられず, PR と MC はさらにわず かに収縮が続いた後に, 逆に原型方向への寸法変化（収 縮の回復）がみられ, PR はほぼ原型に回復した.

表 1 に Point 1 の分散分析の結果を示した. 重合変形 は, $\mathrm{AC}, \mathrm{PR}, \mathrm{MC}$ の 3 種とも色険率 1\% で有意となり， 経日的変形では, $\mathrm{PR}$ 亡 MC が危険率 1\%で有意となっ たが, AC は有意とはならなかった.

図 7 は, Point 1 における測定結果の平均值のグラフ を重合変形と経日的変形に分けて表したもので，縦軸は 原型に対する変化率（\%）を，横軸は測定の段階と開輪 後の時間経過, 図中の縦線は $95 \%$ の信頼限界を示した。 

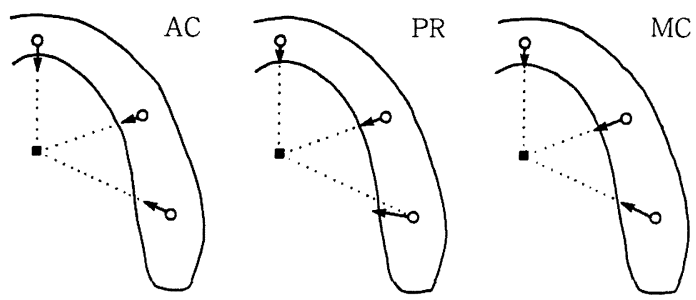

図 8 単純形態 $\mathrm{B}$ の重合変形
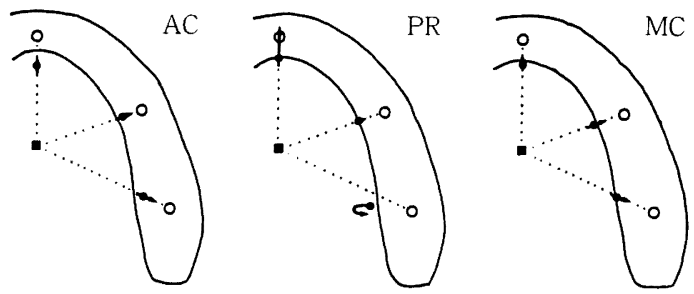

図 9 单純形態 $\mathrm{B} の$ 経日的変形
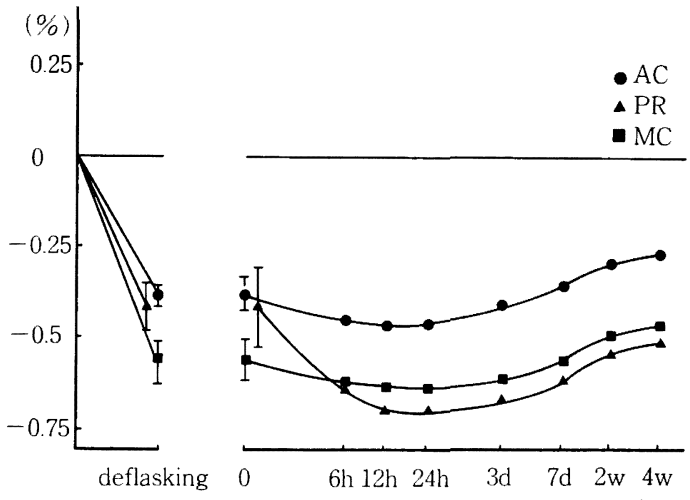

図 10 単純形態 B (Point 1) の重合直後の寸法変化とその 後の経日的寸法変化 (h: hour, d: day, w : week)

重合変形は, AC が $0.45 \%, \mathrm{PR}$ が $0.23 \%, \mathrm{MC}$ が $0.32 \%$ の線収縮率であった.

経日的変形は, AC にはほとんど寸法変化がみられず, PR は 12 時間後まで収縮が続き, その後収縮の回復傾向 がみられ，4週間後では原型より $0.03 \%$ 拡大した状態 となった. MC は 6〜12 時間後まで収縮が続き, その後 回復する傾向が 7 日後までみられ，そのとき $0.30 \%$ の 収縮率を示した。

他の測定点についても, Point 1 とほぼ同様の傾向を 示した.

2）単純形態 B（下顎総義歯を想定した単純形態レジ ン床)

単純形態 $\mathrm{B}$ の各測定点の寸法変化は図 8,9 に示した 通りで, 重合変形は, $\mathrm{AC}, \mathrm{PR}, \mathrm{MC}$ の 3 種ともに, 床全
表 2 単純形態 B (Point 1) の分散分析表

\begin{tabular}{|c|c|c|c|c|c|c|}
\hline & & 要因 & SS & DF & V & $\mathrm{F}$-佰 \\
\hline \multirow[t]{9}{*}{ 杖公変形 } & $\mathrm{AC}$ & 級間 & 1.064 & 1 & 1.064 & $2 \times .7 .76 * *$ \\
\hline & & 呮差 & 0.114 .4 & 28 & 0.004 & \\
\hline & & 合計 & 1.168 & 29 & & \\
\hline & PR & 級䦚 & 1.217 & 1 & 1.217 & $65.94 * *$ \\
\hline & & 损疼 & 0.517 & 28 & $0.01 \%$ & \\
\hline & & 全部 & 1.734 & 29 & & \\
\hline & $M C^{\circ}$ & 新閌 & $2.28 x$ & 1 & 2.288 & $203.68 * *$ \\
\hline & & 梠差差 & 0.315 & 28 & 0.011 & \\
\hline & & 余訪 & 2.603 & 29 & & \\
\hline \multirow[t]{9}{*}{ 的交形 } & $\mathrm{AC}$ & 級間 & 0.546 & 7 & 0.078 & $1-.30 * *$ \\
\hline & & 副基 & 0.611 & 112 & $0.000 . \overline{5}$ & \\
\hline & & 份部 & 1.157 & 119 & & \\
\hline & PR & 影汭 & 1.273 & 7 & 0.182 & $3.73 * *$ \\
\hline & & 䛊㾦 & 5.4 .5 & 112 & 0.049 & \\
\hline & & 份斻 & 6.731 & 119 & & \\
\hline & $\mathrm{MC}$ & 般間 & 0.409 & $\tau$ & 0.0 .58 & $3.93 * *$ \\
\hline & & 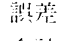 & 1.666 & 112 & 0.015 & \\
\hline & & 合叶 & 2.075 & 119 & & \\
\hline
\end{tabular}

体がほぼ基準点方向に収縮し，例外的に PR の Point 1, 2 は基準点よりやや後方部に向かって収縮した. 経日的 変形では, AC, PR, MCの 3 種は，わずかに収縮が続き， その後原型方向にわずかに回復した.

つぎに, Point 1 についての分散分析の結果を表 2 に, 平均值のグラフを図 10 に示した.

重合変形と経日的変形は, AC, PR, MC の 3 種とも危 険率 1\%で有意となった.

重合変形は, $\mathrm{AC}$ が $0.38 \%, \mathrm{PR}$ が $0.40 \%, \mathrm{MC}$ が $0.55 \%$ の収縮率であった. 経日的変形は， 3 種のレジン とも, 12〜24 時間後まで収縮し, その後回復する傾向が みられ，4週閒後には，AC が $0.26 \%$, PR が $0.47 \%$, MC が $0.43 \%$ の収縮率を示した.

他の測定点についてみると, PR の Point 5 が 4 週間 後に原型よりやや扡大したが, その他の測定点は, Point 1 とほぼ同様の傾向であった.

\section{2. 実 験 II}

1）上枵総義歯

上顎総義歯の各測定点の寸法変化を, 重合変形は図 11〜13 に, 経日的変形は図 14〜16 に示した. 図中の矢印 は基準点を中心とした各測定点の寸法変化の方向を，矢 印の長さは寸法変化量を 50 倍に拡大して示した. 図の 左半分は粘膜面観，右半分は上から第 2 小臼歯および第 


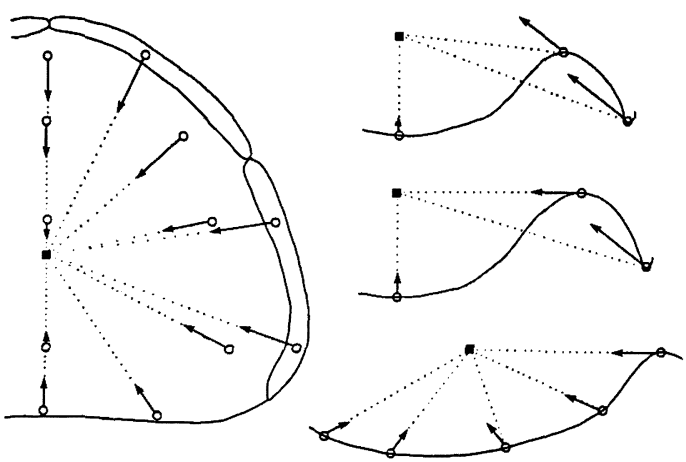

図 11 上頡総義齒(AC) の重合変形

左 : 粘膜面観, 右上 : 第 2 小臼歯前頭面観, 右中 : 第 2 大臼歯前頭面観, 右下 : 正中矢状面観, $\bigcirc$ : 原型の測 定点の位㯰, $\rightarrow$ : 重合変形の方向と変化量 $(\times 50)$,

口: 基準点
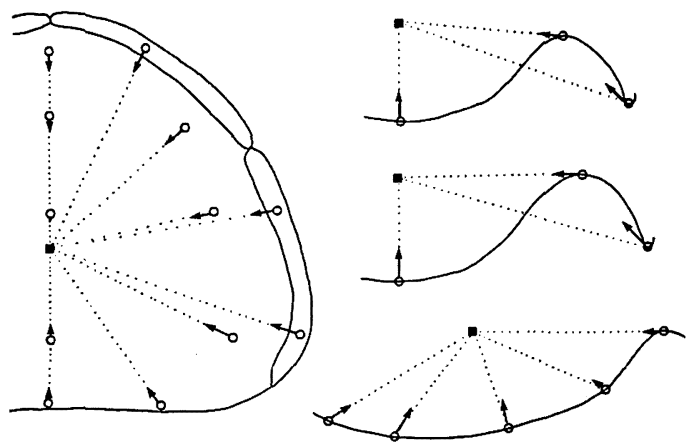

図 12 上頂総義歯 (PR) の重合変形
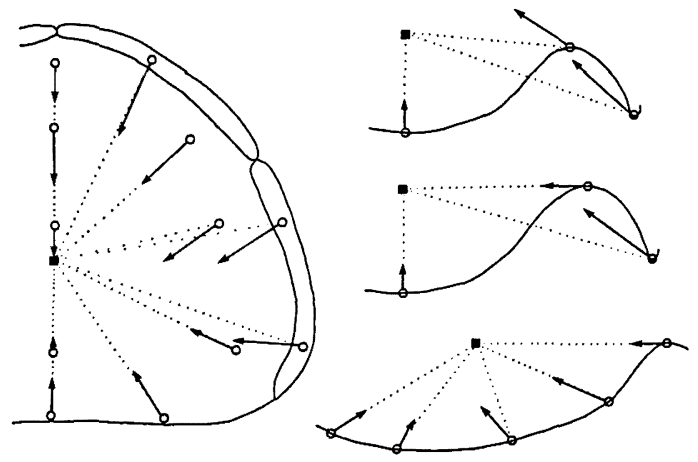

図 13 上頡総義歯 $(M C)$ の重合変形

2 大臼歯相当部の前頭面観と正中矢状面観を 表してい る.

重合変形は, AC, PR, MC の 3 種とも, 各測定点がほ ぼ基準点方向に収縮したが, 粘膜面観では MC の臼歯 部辺縁と小臼歯歯槽頂部が基準点よりやや後方に向かっ て収縮し, 前頭面観では 3 種のレジンの床辺縁部と, AC
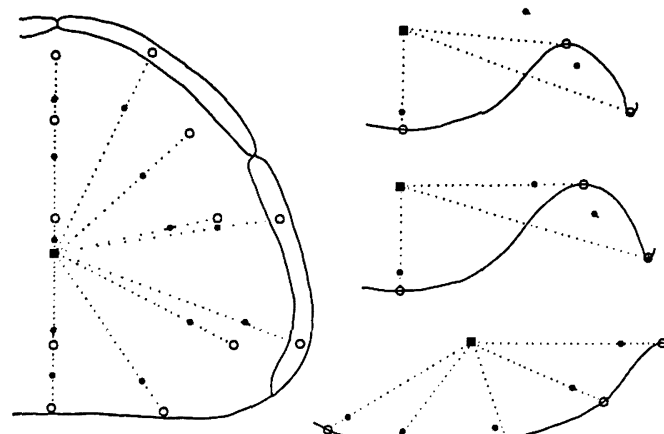

図 14 上頇総義歯 (AC) の経日的変形 $\bigcirc$ : 原型の測定点の位置, $:$ 重合変形の位置 $(\times 50)$, $\rightarrow$ : 経日的変形の方向と変化量 $(\times 50), \boldsymbol{a}:$ 基隻点
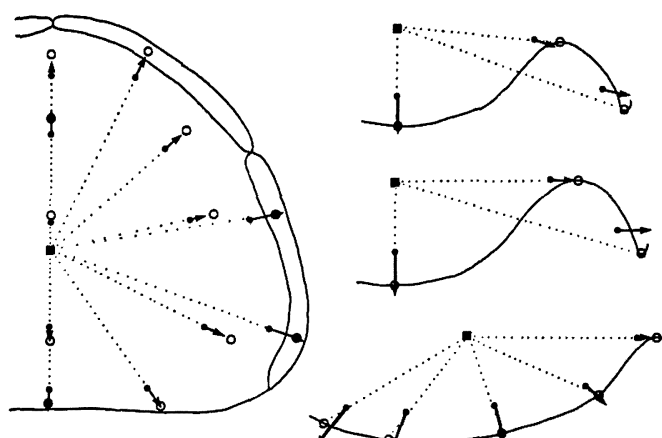

図 15 上䫑総義歯 $(P R)$ の経日的変形
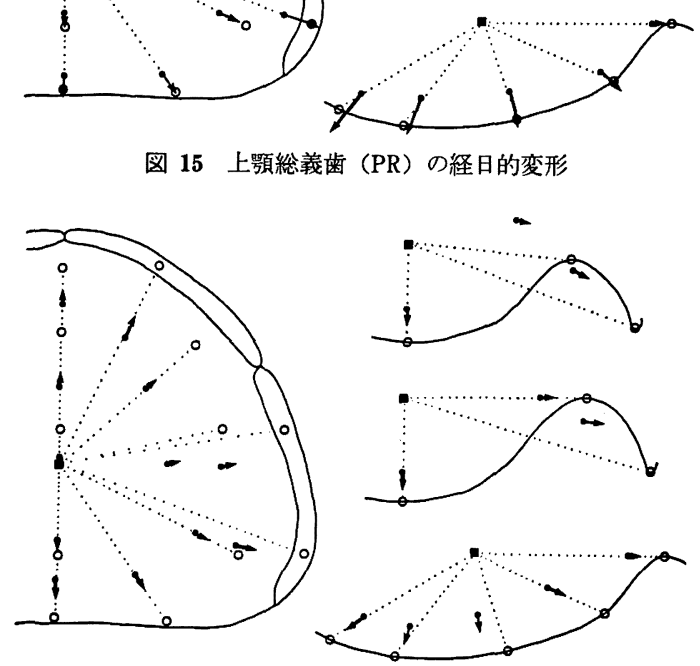

図 16 上顎総義歯 (MC) の経日的変形

と MC の Point 10,12 が，わずかながら床の研磨面方 向に浮き上がる傾向がみられた. また, 口蓋正中部は, 3 種のレジンとも原型粘膜面からの浮き上がりがみられ た.

経日的変形では，AC は，ほとんど寸法変化がみられ ず, PR と MC は, 原型方向への回復がみられたが, 床 辺縁部は研磨面方向一浮き上がりつつ, 収縮傾向の回復 
表 3 上顎総義菌（Point 5) の分散分析表

\begin{tabular}{|c|c|c|c|c|c|c|}
\hline & & 要因 & SS & DF & V & $\mathrm{F}$ - 值 \\
\hline \multirow[t]{9}{*}{ 重合変形 } & \multirow[t]{3}{*}{$\mathrm{AC}$} & 級間 & 1.754 & 1 & 1.754 & \multirow[t]{3}{*}{$647.20 * *$} \\
\hline & & 沾涳 & 0.076 & 28 & 0.003 & \\
\hline & & 分計 & 1.830 & 29 & & \\
\hline & \multirow[t]{3}{*}{ PR } & 級間] & 0.477 & 1 & 0.477 & \multirow[t]{3}{*}{$361.42 * *$} \\
\hline & & 啌差 & 0.037 & 28 & $0.001]$ & \\
\hline & & 合部 & 0.514 & 29 & & \\
\hline & \multirow[t]{3}{*}{$\mathrm{MC}$} & 級閌 & 1.545 & 1 & 1.545 & \multirow[t]{3}{*}{$892.79 * *$} \\
\hline & & 県差 & 0.048 & 28 & 0.002 & \\
\hline & & 畣郭 & 1.593 & 29 & & \\
\hline \multirow[t]{9}{*}{ 経日的变形 } & \multirow[t]{3}{*}{$A C$} & 被间 & 0.059 & $i$ & 0.008 & \multirow[t]{3}{*}{$1.29-$} \\
\hline & & 憘差 & 0.736 & 112 & 0.007 & \\
\hline & & 分計 & 0.795 & 119 & & \\
\hline & \multirow[t]{3}{*}{ PR } & 秋浯 & 0.987 & $\tau$ & 0.141 & \multirow[t]{3}{*}{$34.30 * *$} \\
\hline & & 熦差 & 0.461 & 112 & 0.001 & \\
\hline & & 伶計 & 1.448 & 119 & & \\
\hline & \multirow[t]{3}{*}{$M C^{\circ}$} & 旅間 & $0.61 i$ & $i$ & 0.088 & \multirow[t]{3}{*}{$19.94 * *$} \\
\hline & & 無差 & 0.495 & 112 & 0.004 & \\
\hline & & 含副 & 1.112 & 119 & & \\
\hline
\end{tabular}

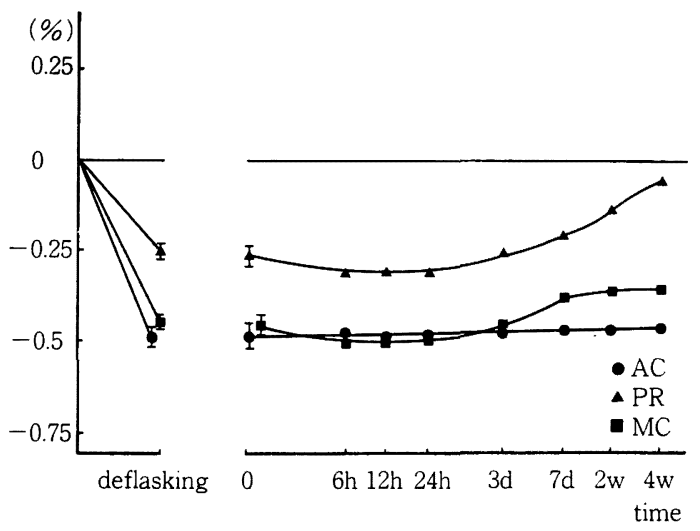

図 17 上䫟総義歯（Point 5) の重合植後の寸法変化と その後の経日的寸法変化 ( $h:$ hour, d : day, w : week)

がみられた. また PR は, ほぼ原型まで回復し, 口蓋正中 部は原型よりやや粘膜面側に沈み込んだ状態となった.

つぎに，上額第 2 大臼歯歯槽頂相当部に設定した Point 5 の分散分析の結果を表 3 に示した。重合変形で は, AC, PR, MC の 3 種が危険率 1\% で有意となり，経 日的変形では, PR と MC が危険率 1\% で有意となった が, AC は有意とはならなかった.

他の測定点の分散分析の結果も Point 5 と同様で, 経 日的変形での AC が有意とはならなかった。

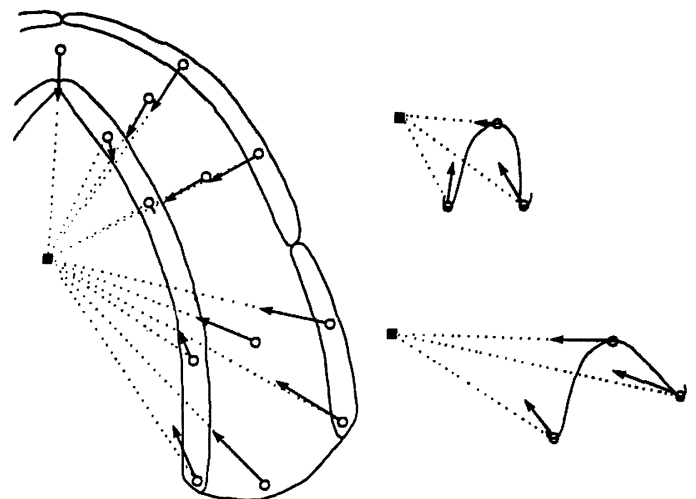

図 18 下顎総義歯 (AC) の重合変形

左 : 粘膜面観, 右上 : 犬歯断面観, 右下 : 第 2 大兒歯断 面推， $\bigcirc$ : 原型の測定点の位置， $\rightarrow$ : 重合変形の方向と 変化量 $(\times 50), \square:$ 基準点

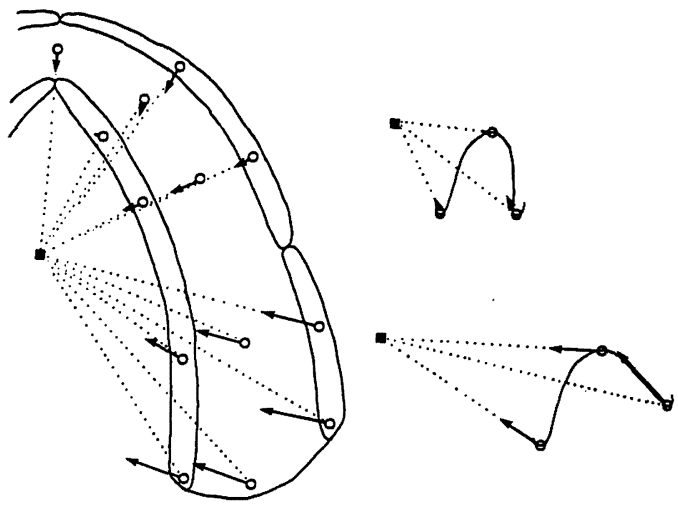

図 19 下狉総義菌（PR）の重合変形

Point 5 における測定結果の平均值のグラフを図 17 に 示し，縦軸は原型に対する変化率（\%）を，横軸は測定 の段階と開輪後の時間経過，図中の縦線は $95 \%$ の信 頼 限界を示した。

重合変形は, AC が $0.48 \%, \mathrm{PR}$ が $0.25 \%, \mathrm{MC}$ が $0.45 \%$ の収縮率であった.

経日的変形は, AC にはほとんど寸法変化がみられず, PR は, 6〜12 時間後まで収縮が続き, その後回復傾向が みられ， 4 週間後では $0.03 \%$ の収縮率であった. MC は 12 時間後までわずかに収縮が続き，その後回復する傾向 が 7 日後までみられ，そのとき $0.36 \%$ の収縮率であっ た.

\section{2）下頡総義歯}

下顎総義歯の各測定点の寸法変化の重合変 形を図 18 〜20に, 経日的変形を図 21〜23 に示した. 図の左半分 は粘膜面観, 右半分は犬歯および第 2 大臼歯相当部の断 面観を表している. 


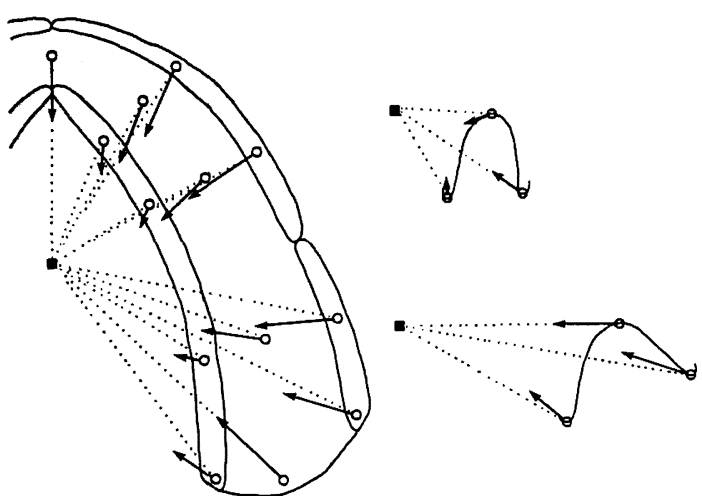

図 20 下顎総義歯（MC）の重合変形

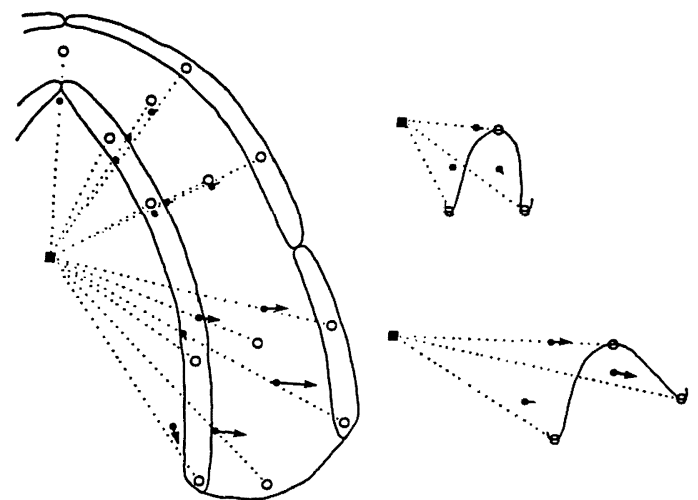

図 21 下額総義歯 (AC) の経日的変形

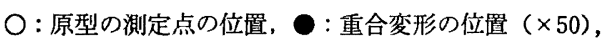
$\rightarrow$ : 経日的変形の方向と変化量 $(\times 50), \boldsymbol{\square}:$ 基準点

重合変形は, $\mathrm{AC}, \mathrm{PR}, \mathrm{MC}$ の 3 種とも, 各測定点がほ ぼ基準点方向に収縮した。しかし粘膜面観では，ACの 犬歯および小白歯相当部の舌側辺縁が基準点よりやや後 方へ向かって收縮し，大白歯の舌側辺縁部が基隻点より やや近心へ向かって収縮した. PR は, 義歯の後縁が基準 点よりやや後方へ向かって収縮し, MC は, 各測定点が 基準点よりやや後方に向かって収縮した. 断面観では, 3 種のレジンの煩側辺縁部が基準点方向に収縮すると同 時に, 研磨面方向へ浮き上がりがみられた。 また, $\mathrm{AC}$ と $\mathrm{MC}$ は, 舌側辺縁部が基準点方向に収縮すると同時に粘 膜面方向へやや変形した. MC は前歯部で, 歯槽頂部が 粘膜面方向への沈み込みがみられた.

経日的変形では, AC は大臼歯から後方がほぼ煩側に 広がるように回復したが，犬萪および小臼歯部はあまり 回復がみられず, 特に近心舌側辺縁部はほとんど寸法変 化がみられなかったＰR はほぼ原型まで回復がみられ

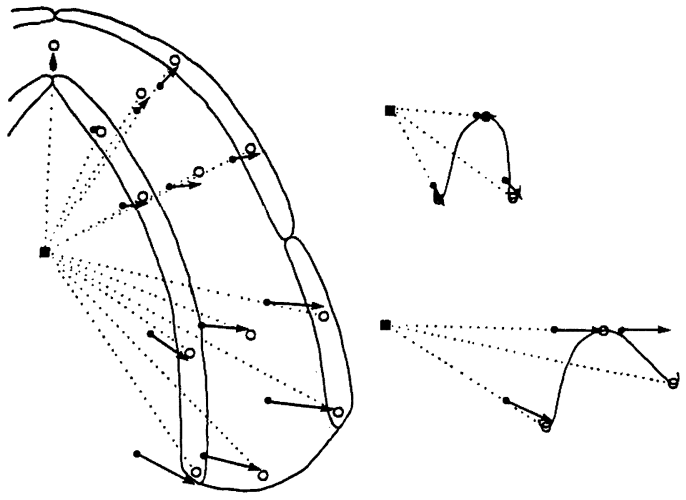

图 22 下頢総義歯 (PR) の経日的変形

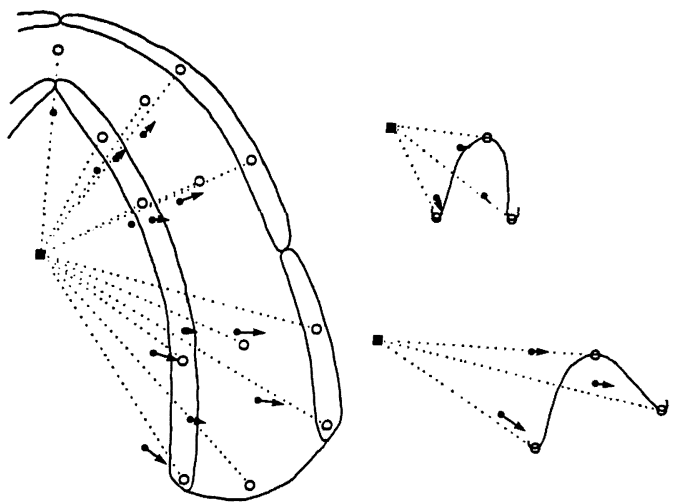

図 23 下瀕総義歯（MC）の経日的変形

たが，臼歯部の煩側辺縁は研磨面方向に浮き上がったま まであった．MC はほぼ原型方向に回復したが，大臼歯 部の煩側辺縁は原型よりやや研磨面側への回復がみられ た.

つぎに，第 2 大臼歯歯槽頂相当部に設定した Point 8 の分散分析の結果を表 4 に, Point 8 の平均値のグラフ を図 24 に示した.

重合変形と経日的変形は，3種のレジンとも危険率 1 \%で有意となった.

他の測定点については, 重合変形は 3 種とも危険率 1 \%で有意となり, 経日的変形は PR と MC は危険率 $1 \%$ で有意となったが ACの犬歯および臼歯舌側辺縁部は有 意とならなかった.

重合変形は, $\mathrm{AC}$ が $0.57 \%, \mathrm{PR}$ が $0.41 \%, \mathrm{MC}$ が 0.67 \%の収縮率を示した.

経日的変形は, $\mathrm{AC}$ は 6〜12 時間後まで, PR と MC は 24 時間後まで収縮が続き, その後 3 種とも回復傾向がみ られた. AC は 2 週間後で $0.35 \%$ の収縮率まで回復し， 
$144-144$

補緅誌

表 4 下影総義歯（Point 8）の分散分析表

\begin{tabular}{|c|c|c|c|c|c|c|}
\hline & & 要因 & SS & DF & V & F - 值 \\
\hline \multirow[t]{9}{*}{ 重合変形 } & \multirow[t]{3}{*}{$\mathrm{AC}$} & 級間 & 2.428 & 1 & 2.428 & \multirow[t]{3}{*}{$832.21 * *$} \\
\hline & & 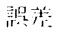 & 0.082 & 28 & 0.003 & \\
\hline & & 公计 & 2.510 & 29 & & \\
\hline & \multirow[t]{3}{*}{ PR } & 級洴 & 1.271 & 1 & 1.271 & \multirow[t]{3}{*}{$282.47 * *$} \\
\hline & & 誤若 & 0.126 & 28 & 0.004 & \\
\hline & & 合刎 & 1.397 & 29 & & \\
\hline & \multirow[t]{3}{*}{$M C$} & 級間 & 3.389 & 1 & 3.389 & \multirow[t]{3}{*}{$280.30 * *$} \\
\hline & & 㳻差 & 0.339 & 28 & 0.012 & \\
\hline & & 分竐 & 3.728 & 29 & & \\
\hline \multirow[t]{9}{*}{ 経田的帘形 } & \multirow[t]{3}{*}{$A C$} & 級間 & 0.909 & 7 & 0.130 & \multirow[t]{3}{*}{$17.13 * *$} \\
\hline & & 师美 & 0.849 & 112 & 0.0018 & \\
\hline & & 含計 & $1.75 x$ & 119 & & \\
\hline & \multirow[t]{3}{*}{ PR } & 級間 & 3.787 & 7 & $0.5+1$ & \multirow[t]{3}{*}{$23.0 .5 * *$} \\
\hline & & 㰨崖 & $\left.2.6_{2}^{2}\right)$ & 112 & 0).023 & \\
\hline & & 公滆 & 6.416 & 119 & & \\
\hline & \multirow[t]{3}{*}{$M C$} & 新閒 & 0.799 & 7 & 0.114 & \multirow[t]{3}{*}{$4.41 * *$} \\
\hline & & 证帣: & 2.902 & 112 & 0.026 & \\
\hline & & 份部 & 3.701 & 119 & & \\
\hline
\end{tabular}

**危候就 $1 \%$ で有意

$\mathrm{PR}$ は 4 週間後で $0.02 \%$ の収縮率で, $\mathrm{MC}$ は 2 週間後で $0.50 \%$ の収縮率まで回復した.

\section{IV. 総括および考察}

上下顎レジン床総義歯粘膜面部の適合性を検討する目 的で, 重合方法の異なる 3 種の床用レジンの重合に伴う 寸法変化（重合変形）と, その後引き続き起こる経日的 な寸法変化 (経日的変形) を三次元座標測定機を用いて 検索するとともに, その結果から，作製した義歯を口腔 内に装着したときの適合性について検討を行った.

\section{1. 実験方法について}

義歯床粘膜面部を, 三次元座標測定機を用いて, 作業 模型から取り出した状態で測定したことにより，従来か

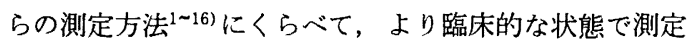
できたと思われる.

測定に際しては, 測定点の形状を改良した高橋ら ${ }^{21)} の$ 方法を採用したことにより, 羽生ら ${ }^{19)}$ の報告よりさらに 高い精度で三次元的に測定できたと考える.

原型上の基準平面と各段階の義歯床の基準平面を, 基 準点を中心として重ね合わせることにより，各測定点の 寸法変化を経日的にとらえることができ，また上下頡総 義歯粘膜面部に多くの測定点を設定し, 寸法変化の方向
34 巻 1 号 (1990)
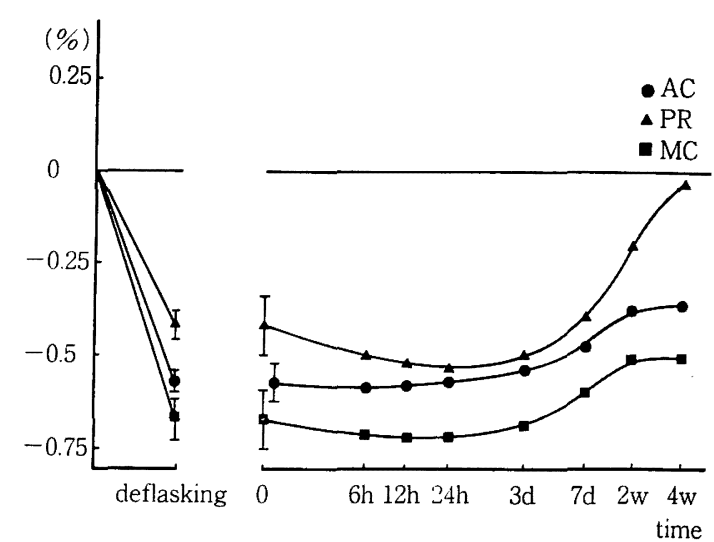

図 24 下顎総義歯（Point 8) の重合直後の寸法変化と その後の経日的寸法変化 $(\mathrm{h}:$ hour, $\mathrm{d}:$ day, w : week)

を明らかにしたことにより，各測定点の寸法変化を義歯 の形態的変化として表すことができたと考える.

\section{2. 上下顎総義歯の寸法変化について}

1）上䫑総義歯

まず，上顎総義歯の重合変形と経日的変形から, AC, $\mathrm{PR}, \mathrm{MC}$ の 3 種のレジンについて検討を行った.

重合変形についてみると, AC は $0.48 \%$ の線収縮率 で, 単純形態 $\mathrm{A} の 0.45 \%$ とほぼ同じ収縮率であり, 羽

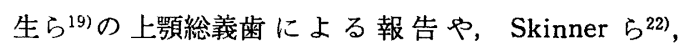
Sweeney $~^{23)}$, Mowery $ら^{8)}$, 原田 ${ }^{24)}$, 奥野ら ${ }^{25)}$ による 加熱重合型レジンの線収縮率の報告とほぼ同様の結果で あった。

PR は $0.25 \%$ で, 単純形態 A 0 $0.23 \%$ とほぼ近似し た収縮率であり, 羽生ら ${ }^{199} の$ 上顎総義歯での線 収 縮率 や, Mowery $ら^{8)}$, 原田 ${ }^{24)}$, 奥野 ${ }^{25)}$ の常温重合型レジン の線収縮率と一致した。 また, Mowery $ら^{8)}$, 原田 ${ }^{24)}$, 奥 野ら ${ }^{25)}$, 永田 ${ }^{26)}$ の常温重合型レジンは加熱重合型レジン の約 $1 / 2$ の収縮率という報告とも, 同様の傾向であっ た.

$\mathrm{MC}$ は, $0.45 \%$ の収縮率で, 単純形態 $\mathrm{A}$ の $0.32 \%$ 上 りやや大きな収縮率を示した. マイクロ波重合型レジン の線収縮率は，丸子 ${ }^{27) か ゙ ~} 0.32 \%$ と報告しておうう，これ よりやや大きな值であった，木村ら ${ }^{28,29)}$ はマイクロ波重 合法で作製した義歯の適合性が加熱重合法より優れてい ると報告し, 内田ら ${ }^{30)}$ はマイクロ波重合型レジンの寸法 精度は加熱重合型レジンより良好で, 注入型レジンと同 等であると報告している。

しかし今回の実験では，丸子27)のマイクロ波重合型レ 
ジンの収縮率は加熱重合型レジンとほぼ同じで，ともに 流し込み型レジンの約 2 倍という報告と，ほぼ同様の傾 向を示し， MC は ACよりわずかに小さい收縮率で $\mathrm{PR}$ の約 2 倍弱の収縮率を示した.

床用レジンの重合に伴う収縮は, Skinner ら 22 や, Schroeder ${ }^{31)}$, 原田 ${ }^{24)}$ はガラス転移点から室温まで冷却 される間の熱収縮であろうと報告しており，このことか ら考えると，MCはマイクロ波 3 分間照射重合時に $100^{\circ} \mathrm{C}$ 以上の温度に達していること年,28)から， AC とほ ぼ同程度の収縮率を示したものと思われる。

経日的変形では, AC は寸法変化がほとんどみられず, PR は 6〜12 時間後まで収縮が続いて，その後 4 週間後 にはほぼ原寸に回復し，MC は 12 時間後までわずかに 収縮し,その後 7 日後まで回復傾向がみられ，7 日後の 収縮率は $0.36 \%$ であった. これらの $\mathrm{AC}, \mathrm{PR}, \mathrm{MC}$ の傾

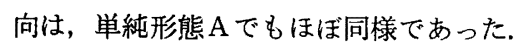

温ら ${ }^{322}$ は, 残留モノマーが流し込み型レジンは加熱重 合型レジンの約 5 倍，マイクロ波重合型レジンは加熱重 合型レジンの約 4 倍と報告し, 床用レジンの吸水量が加 熱重合型レジンで $0.68 \%$, 流し込み型レジンで $1.22 \%$, マイクロ波重合型レジンで $0.92 \%$ と報告している.こ のことから, AC は残留モノマー量が PR や MC に比べ て少なく, 重合操作終了時にほぼ重合を完了しているこ とが考えられ，また吸水量も少ないことから経日的変形 がほとんどなかったものと考える.

$\mathrm{PR}$ と MC は, AC に比べて残留モノマー量がかなり 多くまた吸水量も多いことと, 比較的短時間に取り出し を行ったことから, 内部応力の開放による収縮は, 取り 出し後もさらに続き, その後は吸水によって膨張に転 じ，収縮の回復がみられたと思われる．特に 3 種のレジ ンの中で残留モノマーと吸水量が最も大きいと思われる PR は, この回復傾向が長期間続き, その結果 4 週間後 にはほぼ原寸まで戻ったものと考える.

\section{2）下顎総義歯}

つぎに下顎総義歯について考察すると, 重合変形につ いては, 下顎総義歯の収縮率は, 上䫑総義歯に比べて $\mathrm{AC}$ はやや大きく, PR は約 2 倍の収縮率で, MC は約 1.5 倍の収縮率であり， 3 種のレジンとも下頷総義歯の 方が大きな収縮率を示した。 また, 経日的変形では, AC と MC は上枵総義歯に比べて長期間寸法変化がみられ, PR は上顎総義歯と同様に 4 週間後まで寸法変化がみら れた.

この傾向は, 下顎総義歯が上䫑総義歯に比べて口蓋部 を欠き, 変形しやすいU字型であるため, 重合変形では
上顎総義歯よりやや大きな収縮がみられ，また経日的変 形には長期間の寸法変化がみられたものと思われる. こ の傾向は，ACに比べて未重合の部分が多いことが予測 される $\mathrm{PR} や \mathrm{MC}$ において, 特に顕著に表れたと考え る.

\section{3. 上下顎総義歯粘膜面部の形態変化について}

1）重合に伴う形態変化について

(1) 上頫総義歯

粘膜面観では， 3 種のレジンともほぼ基準点である床 の中心に向かって収縮する傾向がみられた. これは, 単 純形態 $\mathrm{A}$ と同様の傾向であった. 上顎総義歯は, 頇堤や 口蓋などにより複雑な形態をしているにもかかわらず, 上顥総義歯を粘膜面方向から平面的にみると義歯全体が 床の中心に向かってほぼ均等に収縮する傾向が認められ た.

前頭面観では， 3 種のレジンとも各測定点がほぼ基準 点方向に収縮するとともに, 床辺縁部ではさらに研磨面 方向に浮き上がる傾向がみられた．これは重合後の冷却 時に，歯槽部のレジンの重合収縮によって辺縁部のレジ ンに引張り応力が生じ, 浮き上がるような変形をしたの ではないかと考える。

今回の実験では, 床辺縁部は研磨面方向への浮き上が りがみられたが，義歯全体が収縮しているので結果的に は辺縁部は粘膜面に沈み込む状態となった. Anthony

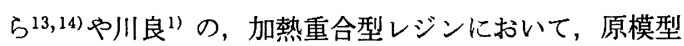
粘膜面と義蒾床粘膜面は, 滪堤の㛲側斜面の みが 接触 し，他の部位は浮き上がっているという報告や，常温重 合型レジンでは Anthony ら ${ }^{14)}$ の萼堤の煩側斜面のみが 接触し，李5) の煩側斜面が他の部位に比べて浮き上がり が小さいという報告とほぼ似た傾向を示した.

また, AC と MC の小臼蒾相当部の歯槽頂では, 基準 点方向に収縮するとともに床の研磨面方向に浮き上がる 傾向が認められ, 羽生ら ${ }^{199}$ の加熱重合型レジンの報告と 同様の傾向であった.

正中矢状面観では， 3 種のレジンとも原型粘膜面から 浮き上がる傾向がみられた. Anthony $ら^{13,14)}$, 平沼2), 羽生ら ${ }^{199}$ の加熱重合型レジンと常温重合型レジンは口蓋 正中部が模型粘膜面から浮き上がったという報告と一致 した. 口蓋正中部が，原型粘膜面から浮き上がったの は, 重合後の冷却時に歯槽部のレジンが収縮し, 薄い口 蓋部のレジンに引張り応力が加わり, 浮き上がったもの と考える.

上䫑総義歯の MC は, 重合の過程でかなり短時間のう 


$$
146-146
$$

ちに温度の上昇と冷却が起きるために，複雑な形態であ る上顎総義歯においてやや不均等な変形がおきたと考え る.

\section{（2）下顎総義歯}

粘膜面観では，AC は義歯全体がほぼ基準点へ向かっ て収縮し, PR は各測定点がほぼ基準点へ向かって収 縮 したが，本の後縁では基準点よりやや後方に向かって収 縮し，MC は床全体が基淮点よりやや後方に向かって収 縮した.この傾向は単純形態 Bでもほぼ同様であった。

下狉総義歯は, 上顎総義歯に比べて変形しやすいU字 型をしているにもかかわらず, 粘膜面方向から平面的に みると, 上顎総義歯と同様にほぼ床の中心に向かって収 縮した. しかし AC と比べて重合後に未重合の部分がや や多いと考えられる PR は, 義㐘床の後方部がやや大き く変形したものと思われる.

断面観では，3種のレジンともほぼ基準点に収縮し， 煩側辺縁部が研磨面方向に浮き上がる傾向がみられた.

この傾向は上嚆総義歯と同様であった。

また舌側辺縁部は, AC と MC が基準点方向に収縮し ながら粘膜面方向に変形し，PR はほぼ基準点方向に収 縮した. PR は埋没材料が寒天印象材なので, 重合変形 時に比較的自由に中心方向に収縮し, AC と MC は埋没 材料が石亮なので中心方向への収縮が抑制され，さらに PR より高い温度で重合操作が行われているため, 粘膜 面方向に変形したのではないかと考える.

重合変形では，3種のレジンは煩側辺縁部が研磨面方 向への浮き上がりがみられたが，義歯全体が基準点方向 に収縮しているため, 粘膜面方向に過圧部が生じやすい 状態であった.

加熱重合型レジンでは, Anthony $5^{13,14)}$ の舌側辺縁部 で最も大きな間隙があり，他の部位は適合性がよく，古 谷3) の舌側辺縁部の適合性が最も悪いという報告や, 常 温重合型レジンでは, Anthony ら ${ }^{14)}$ の舌側辺縁部で最も 大きな間隙があり, 他の部位は適合性がよく, 李5) の舌 側辺縁部と煩側辺縁部の間隙が大きく, 顎堤の煩側斜面 はほとんど間隙がないという報告とほぼ同様の傾向であ った.

以上のことから重合に伴う形態変化は，上下頡総義歯 とも義歯全体がほぼ床の中心に向かって収縮し, 煩側辺 縁がやや研磨面方向に浮き上がる傾问が認められた，下 顎総義歯は，上枵総義歯よりやや大きな収縮と少し複雑 な変形はみられるものの, 上頡総義㐘の口蓋部を取り除 いた形態に近似しているため, ほぼ同じ傾向の形態変化 がみられたと思われる。
34 巻 1 号 (1990)

2）経日的な形態変化について

(1) 上顎総義歯

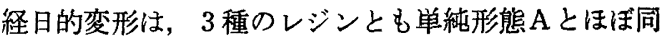
様の傾向を示した.

$\mathrm{AC}$ は重合変形がそのまま残り，PR はほほ原型まで 戻り，辺縁部は研磨面方向に浮き上がり，口蓋正中部は 原型より粘膜面側に沈み込む傾向を示した. MC は，重 合変形がわずかに回復したが，煩側辺縁部の浮き上がり 傾向は，最後まで残った。

\section{（2）下顎総義歯}

経日的変形は，4週間後には，AC は重合変形がわず かに回復したもののそのまま残り，煩側辺縁部は粘膜面 方向に沈み込み，舌側辺縁部は原型からやや間隙のある 状態であった．PR はほぼ原型まで戻り，大臼歯の煩側 辺縁部が研磨面方向へ大きく浮き上がり，原型から間隙 のある状態がみられた，MC は AC と同様に重合変形が わずかに回復したがそのまま残り，煩側辺縁部は粘膜面 方向に沈み込み，舌側辺縁部では，前歯部がほぼ原型に 回復し，臼歯部はやや間隙のある状態であった.

\section{4. 臨床的考察}

最後に上下頡レジン床総義歯を口腔内に装着した場合 を想定し，顎堤粘膜と義歯床粘膜面の関係について考察 を行った。

今回の実験から上下顎総義歯は，義歯装着時に $\mathrm{AC}$, $\mathrm{PR}, \mathrm{MC}$ の 3 種とも, 全体的に収縮傾向を示し, 上䫑総 義歯は，歯槽頂から煩側辺縁にかけて顎堤粘膜を圧迫 し，口蓋部はやや浮き上がった状態が予測され，下䪽総 義歯は，歯槽頂から煩側辺緣部にかけて顎堤粘膜を圧迫 し，歯槽頂から舌側辺縁部では㖽堤粘膜に対してやや間 隙がある状態が予測される。

実際の口腔内の顎堤粘膜には被圧縮性があり，被圧変 位量は個人によりまた部位によって異なっている. 平 田 $^{33)}$ は, 上顎では䫛堤の煩側部は概して歯槽頂部より被 圧縮度が大きいようであり，下顎でも顎堤㛲側部は歯槽 頂より被圧縮度が大きいと報告しており，顎堤粘膜の被 圧縮性は，レジン床総義歯が重合変形により歯槽頂から 煩側辺縁の顎堤粘膜を圧迫した場合の疼痛発現部位に, 深ぐ関連があると考えられる.

日常の臨床において, 総義歯装着後の顎堤粘膜部の圧 迫や疼痛は, 上䫑結節の煩側部や下䫑歯槽堤の煩側部に みられることが比較的多く，今回の実験結果はこの現象 と明らかに符合する.

$\mathrm{AC}$ と MC は, PR に比べて重合による変形が大きい 
ため, 義歯装着時の床の調整にあたっては, やや慎重に 行う必要があると考える.

今回の研究から, 上下顎レジン床総義歯は重合に伴っ て床用レジンの種類により特有の形態変化をすることが 明らかになった. このことから，より適合の良い総義歯 を作製するためには，義歯作製時に用いる床用レジンの 種類や顎堤粘膜の被圧縮性などを念頭において印象方法 を再検討する必要があると考える.

\section{V. 結 論}

上下顎レジン床総義歯の床粘膜面部について, 三次元 座標測定機を用いて, 重合方法の異なる 3 種の床用レジ ンの重合に伴う経日的寸法変化を三次元的に測定すると ともに, この寸法変化に伴う義歯床の形態的変化の特徴 を明らかにするために実験を行い以下の知見を得た.

1. 上下顎レジン床総義歯の重合変形や経日的変 形 は, 床用レジンの重合方法により特徵的な形態変化をす ることが明らかになった。

2. 上頡レジン床総義歯の重合変形は, 加熱重合型レ ジン, 流し込み型レジン, マイクロ波重合型レジンの 3 種とも, 義歯全体が床の中心へ向かって収縮する傾向が 認められた. さらに床辺縁部は, 研磨面方向にわずかに 浮き上がる傾向がみられた.

3. 下顎レジン床総義歯の重合変形は, 3 種のレジン とも, ほぼ床の中心に向かって収縮する傾向が認められ た. 流し込み型レジンは床の後縁が中心のやや後方に向 かって変形し, マイクロ波重合型レジンは床全体が中心 のやや後方に向かう収縮がみられた. また， 3 種のレジ ンとも煩側辺縁部は, 研磨面方向一浮き上がる傾向がみ られた.

4. 上頡レジン床総義歯の経日的変形は, 加熱重合型 レジンには変化がほとんどみられず重合変形がそのまま 残り, 流し込み型レジンは 4 週間後にほぼ原型に回復し たが，床辺縁部は研磨面方向にわすかに浮き上がり，マ イクロ波重合型レジンは 1 週間後までわずかに原型方向 に回復する傾向が認められた.

5. 下顎レジン床総義歯の経日的変形については, 加 熱重合型レジンとマイクロ波重合型レジンは重合時の変 形が 2 週間後まで回復する傾向がみられ, 流し込み型レ ジンでは 4 週間後にほぼ原型に回復する傾向が認められ た. 最終的には, 加熱重合型レジンとマイクロ波重合型 レジンでは重合直後にみられた煩側辺縁部の浮き上がり はそのまま残り, 全体として原型が収縮した形態にとど
まった. 流し込み型レジンはほぼ原寸に戻ったものの, 煩側辺縁部が浮き上がる傾向は残った.

6. 3 種の床用レジンを比較すると, 加熱重合型レジ ンでは, 重合直後に義歯全体が均等に収縮し, 以後経日 的な変化はほとんどみられなかった，流し込み型レジン は, 重合直後に義歯全体が収縮するが, さらに 6〜24 時 間後まで収縮が続き, その後膨張に転じて 4 週閒後でほ ぼ原型に回復した. マイクロ波重合型レジンは, 重合直 後にやや不均等な収縮がみられ，さらに 12〜24 時間 後 まで収縮が続き，その後わずかに回復する傾向がみられ た.

7. 3 種の床用レジンとも，下顥総義歯が上顎総義歯 より,やや大きく変形する傾向がみられた.

稿を終えるに臨み，終始ご愁篤なるご指導ならびにご校閲を 賜りました本学歯科補緅学第一講座羽生哲也教授に哚甚なる感 謝の意を表します.さらに, 研究遂行上および論文作製上多大 のご助言とご鞭撻をいただきました歯科補経学第一講座澤村直 明前助教授に厚くお礼申し上げますとともに，多大なるご支援 をいただきました講座員各位に感謝いたします。

本論文の要旨は昭和 62 年度日本補緅歯科学会九州支部学術大 会 (昭和 63 年 2 月 27 日於福岡), 第 79 回日本補経歯科学会学 術大会 (昭和 63 年 5 月 27 日於東京) および第 15 回福岡歯科大 学学会総会 (昭和 63 年 11 月 19 日於福岡) において発表した。

\section{文献}

1）川良美佐雄 : 床用レジンの填塞・温成法に関する補綴学的 検討一上影総義歯について一, 日大口腔科学, $7: 375 \sim$ 388, 1981.

2）平沼謙二：義歯作用レジンの理工学的試験 とくに, 人工 歯の変位よりみた寸法精度の検砷, 日歯医師会誌, 36 : $849 \sim 856,1983$.

3）古谷 容: 加熱重合レジンの各種嫔塞・温成法に関する研 究一下頡総義菓について一, 日大口腔科学, $9: 366 \sim 379$, 1983.

4）宇美隆生, 青山芳博, 後藤ひろみほか: 可視光線重合型床 用レジンの基礎的研究一第 3 報 適合性の検討一, 日大歯 学, $60: 410 \sim 414,1986$.

5）李 根培: 床用常温重合レジンの重合法に関する臨床的研 究一総義歯の垂直的ならびに床粘膜面の挙動について一, 日大口腔科学, $13: 238 \sim 251,1987$.

6) Woelfel, J.B., Paffenbarger, G.C. and Sweeney, W.T. : Dimensional changes in complete dentures on drying, wetting and heating in water, J Am Dent Assoc, 65 : 495 505, 1962.

7）永田勝久, 佐藤雅彦, 中林宣男ほか：重合収縮の発現部位 
と義歯床の適合精度について, 歯理工誌, $19: 153 \sim 158$ ， 1978.

8) Mowery, W.E., Burns, C.L. and Dickson, G. et al : Dimensional stability of denture base resins, J Am Dent Assoc, $57: 345 \sim 353,1958$.

9) Winkler, S., Ortman, H.R. and Morris, H.F. et al : Processing changes in complete dentures constructed from pour resins, J Am Dent Assoc, $82: 349 \sim 353,1971$.

10) Winkler, $S$. : Clinical evaluation of complete dentures constructed from pour resins, J Am Dent Assoc, 87 : 131 133, 1973.

11) de Gee, A.J., ten Harkel, E.C. and Davidson, C.L. : Measuring procedure for the determination of the three-dimensional shape of dentures, J Prosthet Dent, $42: 149 \sim 153,1979$.

12) Rupp, N.W., Dickson, G. and Lawson, M.E. Jr. et al : A method for measuring the mucosal surface contours of impressions, casts and dentures, J Am Dent Assoc, $54: 24 \sim 32,1957$.

13) Anthony, D.H. and Peyton, F.A.: Evaluating dimensional accuracy of denture bases with a modified comparator, J Prosthet Dent, 9 : 683 692, 1959.

14) Anthony, D.H. and Peyton, F.A. : Dimensional accuracy of various denturebase materials, J Prosthet Dent, 12 : 67 81, 1962.

15) Szmyd, L., Schuessler, C.F. and Brewer, A.A. et al : SAM contourator, model B : an instrument for measuring changes of surface contours, J Prosthet Dent, 14 : 298 306, 1964.

16) Becker, C.M., Smith, D.E. and Nicholls, J.I. : The comparison of denture-base processing techniques. Part II. Dimensional changes due to processing, J Prosthet Dent, 37 : 450 459, 1977.

17）稲永昭彦, 宮口裕美，岡喜七郎ほか：義歯床用レジンに関 する研究 第 2 報 INTOPRESS の床粘膜面部における適 合性について, 福岡歯大誌, $9: 215 \sim 226,1982$.

18）稲永昭彦, 羽生哲也, 本田裕一ほか：義歯床用レジンに関 する研究 第 4 報 歯槽部ワックス量の減量が重合後の床 粘膜面の適合性に及ぼす影響について, 福岡歯大誌, 9 : $603 \sim 612,1983$.

19）羽生哲也, 稲永昭彦, 武内哲二ほか: 床用レジンの重合変
形について 第 1 報 上額総義歯粘膜面部の三次元的検 討, 補猳誌, $29: 310 \sim 318,1985$.

20）澤村直明，武内哲二，白木 洋ほか：光重合レジンの補緅 的考察 第 2 報 光重合を応用した表面処理による義菌床 粘膜面の寸法変化について (1), 補緅誌, $29: 319 \sim 324$, 1985.

21）高橋 裕, 武内哲二, 澤村直明ほか : 三次元座標測定機に よるレジン床義歯の測定精度の検捨一測定点の形状につい て一, 補緅誌, $32: 1358 \sim 1362,1988$.

22) Skinner, E.W. and Cooper, E.N. : Physical properties of denture resins: Part I. Curing shrinkage and water sorption, J Am Dent Assoc, 30 : 1845 1852, 1943.

23) Sweeney, W.T., Paffenbarger, G.C. and Beall, J.R. : Acrylic resins for dentures, J Am Dent Assoc, 29:7 $33,1942$.

24）原田義雄 : 義歯床用常温重合樹脂に関する研究, 口病誌, $32: 291 \sim 312,1965$.

25）奥野善彦，丸岡寛昭，野首孝柌ほか：注入型レジンに関す る基喽的研究，阪大歯学誌， $17: 46 \sim 55,1972$.

26）永田勝久：歯科用流し込みレジンに関する研究（II）架橋 凮濃度と重合時の加圧が寸法精度におよぼす影響につい て, 歯理工誌, $17: 239 \sim 246,1976$.

27）丸子健二 : 各種重合法による義歯床用レジンの寸法変化に ついて, 九州歯会誌, $42: 903 \sim 917,1988$.

28）木村 博, 寺岡文雄, 大西寬保ほか：マイク口波の歯科人 の応用 (その 2)ーレジンの適合性一, 歯材器, $2: 451 \sim 457$, 1983.

29）木村 博, 游 本淵, 寺岡文雄: 義歯床用レジンの開発に 関する研究（第 1 報）人工歯の移動と適合性について, 歯 材器, $6: 888 \sim 893,1987$.

30）内田欣臣, 風本史江, 尾形和彦ほか：マイク口波重合型義 歯床用レジンの寸法精度，補緅誌，33：114 118， 1989.

31) Schroeder, A.: Die Eignung der Methakrylate als Prothesenstoffe im Lichte neuer Untersuchungen, Schweiz Monatsschr Zahnheilkd, 63 : 961 971, 1953.

32）温 月姗, 宮崎光治, 堀部隆：マイクロ波重合法による 義歯床用レジンの理工学的性質 第 1 報 照射時間による 影響, 福岡歯大誌, $14: 158 \sim 162,1987$.

33）平田幹夫：無歯䫟粘膜の被圧縮度に関する臨床的研究, 補 緅誌, $3: 14 \sim 27,1959$. 